necessary to go over his paper in detail. He has advanced nothing new-nothing which has not already been answered by Professor Ramsay and others. One cannot help remarking, however, that it does seem strange that he should quietly ignore the fact that no supporter of the glacial erosion theory has ever asserted that all rock-basins are of glacial origin. Will he kindly tell us what glacialist has expressed disbelief in the existence of special areas of subsidence, or which of us has maintained that volcanic action and the movements accompanying that action cannot possibly have resulted in the formation of lake-basins. He states that I appear to assume that faults "can produce no effect at the surface." I neither assume nor assert that such is the case, as any unprejudiced reader of the passage referred to by Mr. Judd cannot fail to see. Professor Ramsay and they who follow him have all along been careful to admit that lakes are by no means exclusively of glacial origin. They have not ridden their hobby to death, but this is just what Mr. Judd has done with his along the shores of "Lake Balaton in Hungary."

Grological Servet, Perth, 31 st January, 1876 .

\title{
MR. JUDD AND THE GLACIAL EROSION OF LAKES.
}

Sir,-I have read Mr. Judd's paper on the origin of Lake Balaton in Hungary ${ }^{1}$ with interest, and also his eoncluding observations, in which he proceeds to argue from the special to the general against the views of the "Scotch Geologists" regarding the glacial origin of lakes. I think it will occur to most readers, that however ably Mr. Judd has stated his case, his conclusions are not warranted by his facts; and that, in bringing the cases of certain large lakes in Ireland, Hungary, the Holy Land, and Central Africa, as evidences against the truth of the views propounded and illustrated by Professor Ramsay, he has not kept within that logical groove of reasoning for which most of his papers are distinguished.

Without wishing to enter the lists with the author of the paper, I venture to state two or three points on which his conclusions are, as it seems to me, open to objection. In summing up he says : "We have demonstrated that the basins of the largest lakes in our own islands, in the Alpine regions of Europe, and in equatorial Africa, could not possibly have been formed by the supposed excavating power of ice. We have also shown that in each of these cases there is the strongest ground for believing the districts in question to have been subjected to powerful subterranean movements; and that these were quite competent to produce the depressions in question." Well, we may admit that Lough Neagh, Lake Balaton, the great African Lakes, and, I will add, the Dead Sea and Jordan Valley, were not and could not have been formed by glacial erosion. But after this admission, does it by any means follow that Loch Lomond, Lough Doon, ${ }^{3}$ Windermere, the Welsh tarns and lakes, and some of the lakes on both sides of the Alps, were not so formed? Surely Mr. Judd will not venture

1 Geol. Mag. No. 139, January, 1876, p. 5.

${ }^{3}$ See J. Geikie, "The Great lce Age," p. 294.

${ }^{2}$ Ibid. p. 15. 
on such a conclusion; nor will any one who has had a wide experience of the ways and means by which terrestrial features have been modelled. Dame Nature is not so short-handed, that where one agency fails, she cannot find another. If Vulcan is at work in one place, so also is the Ice King of the North in another. For my part, I believe that in the formation of lakes numerous physical causes have at various times, and in divers places come into play. In the Jordan Valley it may be concluded, from the scanty observations of travellers regarding its geology, that there has been a great fracture ranging along the base of the Moabite table land. In the ease of Balaton Lake there may have been a subsidence in a volcanic district; in that of Lough Neagh, fractures of the strata before the Glacial Period ; in many large lakes in the centre of Ireland, there has been the dissolution of the limestone by water charged with carbonic acid gas; and in the Cheshire plains there has been subsidence due to the melting of subterranean beds of salt, as Mr. Ormerod long since suggested. These are all diverse processes by which lakes are formed by other than glacial erosion. But none of them apply in the cases of the rock-basins of British mountains and other districts where the evidences of glacial erosion are so striking, and where there are no evidences of recent fractures of the strata, nor of volcanic terrestrial movements, nor of solution of calcareous beds, nor of solution of beds of salt. On the other hand, in default of other agencies, we are forced to recognize the influence of those which have evidently been at work in these districts; and I cannot think that, in throwing over so completely the theory of glacial erosion for all lakes, Mr. Judd has sufficiently weighed the grounds for its acceptance, which have from time to time been alvanced by its author, Professor Ramsay, or by those who support his views, such as Gastaldi of Turin, or James Geikie amongst the "Scotch Geologists."

I may observe, in conclusion, that both in the original memoir in the Journal of the Geological Society, and in the Physical Geology of Great Britain, Professor Ramsay especially eliminates "craterlakes, lagoons, and the lakes of Central Africa," from the class of lakes to which his theory applies; so that Mr. Judd's objection has been anticipated by the author of the theory himself. (Phys. Geol. and Geog., 3rd ed. p. 173.)

Geological Survey Office, Dublin, Edward Hule. January, 1876.

MR. JUDD ON GLACIAL EROSION AND SUBAERIAL DENUDATION.

SIR,- To fight other people's battles, especially when the other people are perfectly well able to take care of themselves, is palpably unnecessary, and might smack of meddlesome interference; besides well-intentioned advocacy is liable to damage even a good case, unless the advocate is specially fitted for his task; and then-but no, I won't go on. I have given reason enough why I should not try to cliscuss the arguments advanced by Mr. Judd in your January Number against the theory of the Glacial Erosion of Rock Basins.

But there are one or two points in that paper which I do feel less 